\title{
Animal welfare in Covid-19 pandemic: A review on impact and managemental strategies
}

\author{
Aneela Knawal ${ }^{1}$, Aiman Zahra ${ }^{1}$ and Tanveer Hussain ${ }^{2 *}$ \\ 1. Department of Biology, Virtual University of Pakistan, Multan-Pkistan \\ 2. Department of Molecular Biology, Virtual University of Pakistan, Lahore-Pkistan \\ *Corresponding author's email: tanveer.hussain@vu.edu.pk \\ Citation
}

Aneela Knawal, Aiman Zahra and Tanveer Hussain. Animal welfare in Covid-19 pandemic: A review on impact and managemental strategies. Pure and Applied Biology. Vol. 10, Issue 3, pp872-877.

http://dx.doi.org/10.19045/bspab.2021.100089

Received: 25/04/2020 Revised: 01/11/2020

Accepted: 30/11/2020

Online First: 30/12/2020

\section{Abstract}

The novel coronavirus (COVID-19), third acute infectious illness, instigated by severe acute respiratory syndrome coronavirus 2 (SARS-CoV-2) infections, confirmed as infectious disease pandemic globally by World health organization, spread rapidly in China and then worldwide. As the novel coronavirus pandemic spreads globally with overwhelming outcomes on individual health, pets and animals have also become unnecessary targets amongst the pandemic panic. In the face of a global pandemic, domesticated and companion animals are relegated to the most vulnerable stratification of society. Prolonged lockdown has greatly reduced food resources for animals. This situation is worrying for all of us that so far the welfare of animals in lockdown situations has not been managed. The author provides an overview of rapidly expanding COVID19 current perspective, its impact on domestic, pets, wild animals and managemental strategies are also discussed. Inappropriately, even though pets and other animal species have continually served as sentinels for emergent transmissible infections, they are currently not included in prerogative of any federal agency and are not under reconnaissance. This review also highlights the role of organizations that are providing food supplies for pets in this pandemic of COVID-19. This article also emphasizes on programmatic and legislative developments of animal welfare and offers suggestions to protect the nature, pets and wildlife during pandemic situations. There is also a need to divert the attention of people towards the safety of domestic animals as well as wild animals are compulsory for their survival.

Keywords: Animal; COVID-19; Domestic; Lockdown; Pandemic; Survival; Wildlife

\section{Introduction}

Domestic animals include dogs, cats, rabbits, cows, buffaloes, sheep and goats etc. and the most prevalent and common domesticated mammals called Felis catus (cats) and Canis femiliaris (dogs) have very well built interaction with human beings throughout the world [1]. For about fifteen thousand years ago, humans and domestic dogs are in strong association [2] and role of dogs in our community is of great concern as they serve as working animals, providing protection, being good companion and can be the sacred icons while living with their owners [3]. Impact of cats on wild creature is negative due to hybridization [4], disease [5] and 
predation [6]. Stray cats are listed among the top 100 protruding creatures [7] and biologist are paying great attention on them due to their worst impact on wild creatures [8]. While certain problems are also associated with domestic dogs [9] like they affect the economy of a country and can also cause harm to their owners by biting. They also attack on livestock living in a herd and also a source of transmission of certain diseases like parasitic as well as viral like rabies [10]. Dogs are also responsible for transmission of about sixty different types of zoonotic infections to humans [11].

Despite of domestic animals, wild animals are also of great concern. There are more chances of transfer of pathogens due to frequent interaction of wild animals and humans. Migration of mammalian species and variations in their body mass might change the alliance among wild animals and human beings. Development of agricultural land, deforestation, urbanization, climate change and intensification in domestic animal production are the mass impacts of phylogenesis leads towards lowering of number and variations of feral mammalian creatures and results in number of pandemics cases. An example of this is migration of bat species in Malaysia which results in an outbreak of a new viral disease Nipah, transmitted to humans from pigs after getting infection through bats [12]. Diseases that can be transferred from animals to humans known as zoonotic disease either through direct means (Vector) or indirectly (Food) and vice versa like animals can also get infected from humans happened in past A(H1N1) pdmo9 influenza transferred to pigs from humans [13].

COVID-19 a new viral disease originated in Wuhan, a city of China in December 2019 and about 76,769 people got affected across the globe [14]. COVID-19, a zoonotic disease transmitted to humans from bats and can also be transmitted to animals in close contact to infected people. This pandemic is affecting the world including humans, domestic animals, pets and wild creature in different ways. This study aims to predict the impact of COVID-19 on domestic, pets and wild creatures, identifying the problems, purposing the solutions by reviewing the literature. By the current pandemic, we aim to provide clear views regarding the adoption strategies, informing people about current issue, providing a platform for future research and basis for collaboration among human welfare and human health organizations.

\section{Current perspective}

Many viral as well as parasitic diseases have effected humans and animals in different ways in past. These viral diseases like Influenza, SARS and many other diseases have affected a huge number of people worldwide. In current scenario world is in danger due to COVID-19 outbreak including humans as well as animals. Animals including domestic, wild and pets are the victims of this pandemic viral disease. During the current situation, humans having animals as pets are in great trouble because if they get sick due to COVID-19, then who will take care of their pets, is a question. People having this viral disease have to take proper precautions while dealing with their pets as they can get affected. According to a report, a case has been reported by Chinese Government that a dog got infected with COVID-19 as its owner was also infected with this virus. So it is suggested that humans who are infected with COVID-19 are advised to stay away from their pets as there are chances of transmission because it is a zoonotic infection (sharing of diseases between humans and animals) (OIE, 2020). Another case has been reported by the US Government in early April, a tiger named Nadia got infected with COVID 19 at Bronx Zoo, New York City (Report by National Veterinary, Services Laboratory). Some cats 
also become ill as the virus entered into their body after exposure to a zookeeper who was suffering with this virus, reported by CDC and the World Health Organization for Animal Health. However, pets are not the cause of spreading of virus. But pet owners have to be careful and should take hygienic measures while dealing with their pets. It is better to stay away or ask another person to take care of their pets because pets also play a great role in our daily lives as they are our best companion said the Dr. Gail Hansen, DVM (Humane Society Veterinary Medical Association).

\section{Impacts of COVID-19 on pet animals}

To the best of my knowledge, coronavirus is not transmitted directly from humans to animals in Pakistan. However certain indirect losses occurred due to the onset of this virus. In Pakistan, several pet animals died at pet shops due to improper feed and care during continuous lockdown across the country. In Karachi's Empress Market, about 70\% of pets were found dead. As pet shops owners business was blocked due to lockdown, they were also unable to feed their pets, even they have to lock them in cages at night (The Daily newsletter, COVID 19).

During this pandemic, so much fake news is circulating like animals are a source of transmission and spreading of COVID-19. Due to this fear, people in China thrown out their pet dogs and cats in the streets in city of Shanghai and Tianjin city, Hebei Province, China. About 30 pet cats and 40 dogs have brought into a shelter as their owners got scared from rumors that dogs and cats can transmit COVID and think that they can't feed them any more (Israel Society for the Prevention of Cruelty to Animals).

Impacts of COVID-19 on wild creature COVID-19 also has some impact on wild animals like according to a report, Margala Hills National Park, Islamabad, Pakistan, has 3 families of common leopard. Wild creatures including martins, fox, wild boars, barking deer, porcupines and jackals came down and wonder with joy in empty places as humans are under lockdown due to COVID19 (IWMB, 2020).

On the other hand in Paris, due to scarcity of food, wild animals got a chance to enter the big cities in search of food as streets are empty due to lockdown. It has been reported that a deer is seen on underpass searching the food in Nara, a city of Japan while a Wild Boar has also found in Barcelona. In capital city of Uttarakhand, Dehradun, India, a stage picture goes viral on social media. A group of Wild Turkeys is also roaming on the streets of Oakland, California reported.

In china wildlife trade is banned due to COVID-19 outbreak as they think Pangolin are an intermediate host for its transmission. A numerously sold small wild animal on the earth is being snatched from the forests of Africa and Asia reported by IUCN (International Union for Conservation of Nature). They brought into the local markets of Vietnam and China and being sold in black and used in preparation of some medicines despite of the fact that they are not medically important. In January 2020, China imposed a ban on the trade of Pangolin including many other wild animals due to COVID-19 pandemic. This results in negative impact on wild animals.

\section{Strategies}

Certain strategies have adopted to save the animals from this COVID-19 pandemic, discussed below:

\section{Tool kit}

COVID-19 spread fear among people as well as animals, here is a good news for animals that researchers made a tool kit which rescues the employee at shelters and working with animals in case of being positive. The aim of this tool is to help out the staff and prepare them if there is any pets influx (Humane Society of United States).

\section{Role of organizations}


Many international organizations are engaged in providing shelters to pets are enlisted in (Table 1).

Table 1. Name of international animal welfare organizations

\begin{tabular}{|c|c|}
\hline Name of organization & Role \\
\hline Fairfax Country Animal Shelter & Provides shelter to animals \\
\hline Human Rescue Alliance & Supply food to animals \\
\hline Loudoun County Animal Services & Provide shelter to animals \\
\hline Prince William County Animal Control Bureau & Provide shelter to animals \\
\hline William George's County Animal Services & Supply food and provide shelter \\
\hline Animal Welfare League of Arlington & Provide shelter to animals \\
\hline Animal Welfare League of Alexandra & Provide shelter to animals \\
\hline
\end{tabular}

\section{Provision of food supplies}

Many organizations are providing food supplies for pets in this COVID-19 pandemic. An organization naming Humane Rescue Alliance is providing food to pet animals according to their weight and species. Resource depletion due to COVID19 pandemic is affecting the whole family along with their pets,words by vice president of community programs Lauren Lipsey at Humane Rescue Alliance.

\section{Adoption of animals}

To protect the nature and wildlife, adoption of animals is on increase now a day. About fifty-five percent of dogs have been adopted which is a high number as compared to last year. There is also a decrease in pet prices to ease the people during this pandemic (Report by HALO Animal Rescue in Phoenix, 2020). Meanwhile there is good news that these abandoned pets, cats and dogs got adopted by lot of pet lovers (Tel Aviv SPCA) and the number goes up to 40. A thought also hitting that when the coronavirus time will over, people who owned these abandoned animals may return them back due to their busy routine or money issue said Haya Beili, a volunteer and member of board at Jerusalem animal shelter. This time is precious for people to build relations between new owners and their pets.

People must have to contribute in adoption of living creatures and reduce their numbers in shelters (Humane Society of Southern Arizona, 2020). A huge number of people rush into shelters to adopt pets and this makes shelters empty. New owners feel comfortable with their new companion animals (Report by Riverside County animal shelter in South California, 2020). After Kiwis responded to SPCA'S call for help, about eight hundred animals were adopted and brought to new places to live. At the onset of level 4 lockdown aimed COVID-19, organizations gave a call for charity.It's a golden time for public to adopt furry friends, said Andrea Midgen, CEO SPCA. As it will be ideal period for KIWIS by adopting furry family members and spending quality time with them. And Kiwis also gave a good response to this call by adopting about 828 animals.

\section{Caretakers for pets}

Certain steps have taken by the society for their pets in collaboration with an international animal welfare organization, Eight DC, Maryland Virginia during this pandemic COVID-19. It becomes need of hour as many people are in quarantine leaving their pets alone with no care. The society has to take the precautionary measures for their pets in case if owner is suffering with COVID-19. The best and safe place for pets is to keep them at homes by appointing a person who should take care of them. In case of unavailability of such person the next option is to avail boarding facility 
with complete instructions including tagging, vaccination and prescriptions etc.

\section{Discussion and Conclusion}

The interdependence of environment, animals and humans is a topic of attention because it is a cyclic process of transmission. Due to increase in population, less living space, frequent travelling and migration of animals is at its peak now a day. All these things need proper monitoring as chances of viral transmission among animals, humans and environments are increasing day by day and sociological affects are also a part of consideration (COVID-19 One World-One Health, 2020).

Wild animal trade is a point of discussion as they are a source of pandemics like COVID 19 (New York Times, 2020). Although this pandemic COVID-19 have originated from Chinese market but such markets also exist throughout the world and can be the reason of such type of viral pandemics in future. So wildlife trade needs some restrictions. Tropical diseases tend to have animal reservoir (conservation News, 2020). Human activity such as deforestation, degradation, mining and logging leads to the migration of animals from forests to populated areas creating mess in cities and resulting in epidemics. The need of hour is to stop such activities and protect nature and wild animals. Other way to avoid such pandemics is to adopt wild creature with proper care. These creatures will be good companion in these quarantine days. We must take care of nature to take care of ourselves. For this Government have to implement some rule regarding maintenance of community conservancies, national parks and zoos (Conservation News 2020).

Public health and Veterinary Services must have to contribute collectively for infected people who are in direct contact with domestic animals. WHO advised public to adopt certain precautionary measures while visiting wet markets, live animal markets or animal product markets. People should avoid touching eyes, nose or mouth of animals, and sanitize hands after touching animal products like meat, milk etc. They also have to take care while visiting live markets to avoid direct contact with stray cats, dogs and bats etc. (WHO, 2020).

To the best of our knowledge adoption of living creature will be a source of harmony during this CPVID-19 pandemic. People have to adopt the animals to engage themselves with furry companions during this lockdown situation. Pakistan Government and health care organizations must have to take steps for the care of wild creatures. Pet animal at homes and at shops also needs to be monitored properly.

\section{Authors' contributions}

Conceived and designed the experiments: $\mathrm{T}$ Hussain, Performed the experiments: A Kanwal \& A Zahra, Analyzed the data: A Kanwal \& A Zahra, Contributed materials/ analysis/ tools: A Kanwal, A Zahra \& T Hussain, Wrote the paper: A Kanwal, A Zahra \& T Hussain.

\section{References}

1. Ferreira JP, Leitao I, Santos-Reis M \& Revilla E (2011). Human-related factors regulate the spatial ecology of domestic cats in sensitive areas for conservation. PLoS One 6(10): 1-10.

2. Driscoll CA \& Macdonald DW (2010). Top dogs: wolf domestication and wealth. J Biol 9(2): 1-6.

3. Serpell J(1995). The Domestic Dog: Its Evolution, Behaviour and Interactions with People. Cambridge University Press, UK. pp. 79-102.

4. Yamaguchi N, Kitchener AC, Driscoll CA, Ward JM\& Macdonald DW (2004). Craniological differentiation amongst wild-living cats in Britain and southern Africa: natural variation or the effects of hybridization. Anim Conserv 7(4): 339351. 
5. Fredebaugh SL, Mateus-Pinilla NE, McAllister M, Warner RE\& Weng HY (2011). Prevalence of antibody to Toxoplasma gondii in terrestrial wildlife in a natural area. $J$ Wildl Dis 47(2): 381392.

6. Van-Heezik Y, Smyth A, Adams A\& Gordon J (2010). Do domestic cats impose an unsustainable harvest on urban bird populations. Biol Conserv 143(1): 121-130.

7. Lowe S, Browne M, Boudjelas S \& De Poorter M (2000). 100 of the world's worst invasive alien species a selection from the Global Invasive Species Database. Published by The Invasive Species Specialist Group (ISSG) a specialist group of the Species Survival Commission (SSC) of the World Conservation Union (IUCN). 12 p.

8. Calver MC, Grayson J, Lilith M\& Dickman CR (2011). Applying the precautionary principle to the issue of impacts by pet cats on urban wildlife. Biol Conserv 144(6): 1895-1901.

9. Young JK, Olson KA, Reading RP, Amgalanbaatar S\& Berger J (2011). Is wildlife going to the dogs? Impacts of feral and free-roaming dogs on wildlife populations. Biosci 61(2): 125132.
10. Knobel DL, Cleaveland S, Coleman PG, Fevre EM, Meltzer MI, Miranda MEG, Shaw A, Zinsstag J\& Meslin FX (2005). Re-evaluating the burden of rabies in Africa and Asia. Bull World Health Organ 83(1): 360-368.

11. Matter HC\& Daniels TJ (2000). Dog ecology and population biology. In: Macpherson, C.N.L., Meslin, F.X., Wandeler, A.I. (Eds.), Dogs, Zoonoses and Public Health. CABI, Wallingford, UK. pp. 17-62.

12. Chua KB, Chua BH \& Wang CW (2002). Anthropogenic deforestation, El Niño and the emergence of Nipah virus in Malaysia. Malays J Pathol 24(1): 1521.

13. Grøntvedt CA, Er C, Gjerset B (2013) Influenza A(H1N1)pdm09 virus infection in Norwegian swine herds 2009/10: the risk of human to swine transmission. Prev Vet Med 110(3-4): 429-434.

14. Srivastava N, Baxi P, Ratho RK \& Saxena SK (2020). Global trends in epidemiology of Coronavirus disease 2019 (COVID-19). In: Coronavirus Disease 2019 (COVID-19). Springer: Singapore. pp. 9-21. 